\title{
A KITERJESZTETT KÖNYVTÁR AZ AR LEHETŐSÉGEI A TARTALOMSZOLGÁLTATÁSBAN
}

\author{
Modla Márk \\ SZTE Klebelsberg Könyvtár \\ mark.modla@ek.szte.hu \\ ORCID 0000-0002-3192-1748 \\ Molnár Sándor \\ SZTE Klebelsberg Könyvtár \\ sandor.molnar@ek.szte.hu
}

DOI: 10.31915/NWS.2018.11

The expanded library - the opportunities of the AR in content-management In the 21st century, library content services provide users with many repositories and databases, resulting in millions of pages of documents accessible online. Although access to information has become much simpler than it was in previous years, there is still a development potential in the methods of access to library contents. Therefore, modern technology allows for the opening of new ways to enable the provision of this accumulated knowledge. There are several solutions, most of them being applied in the entertainment industry today but in the near future, they might be suitable for libraries, as well. Augmented reality is such an opportunity. The purpose of the paper is to present the technological possibilities and how they can be adapted in the library world. It also presents an application developed in the University of Szeged Klebelsberg Library and it shows how this technology can help our users, researchers and librarians work, as well.

Keywords: augmented reality, digital content providing, expanded information, mobile application, digital library, furure libraries

\section{Bevezetés}

A fiatalok és a könyvtári közeget újonnan használók új típusú tájékoztatása új lehetőségként jelenhet meg. A modern eszközök egyre jobban befolyásolják a mindennapjainkat, a könyvtári szolgáltatásokat és a digitális anyagokat. Célunk bemutatni egy, az SZTE Klebelsberg Könyvtárban elkészült kiterjesztett valóság, vagyis az Augmented Reality (továbbiakban AR) alkalmazást, mely kísérlet hasznos segítséget nyújthat a modern technológia segítségével a felhasználóknak. Ez új típusú szolgáltatások bevezetését valamint alternatív lehetőségeket ad a tartalomszolgáltatás területén. Az említett alkalmazást kollégámmal valósítottuk meg, mely elsősorban az offline tartalomszolgáltatást közelíti meg, mint ahogyan maga az írás is ezt a területet öleli fel.

\section{Augmentált Realitás? - Kiterjesztett Valóság!}

A technológia innovatívnak tünik, valójában azonban nem is annyira új keletü. Az elméleti háttér már a 80-as 90-es években is megvolt, a mindennapokban azonban csak az elmúlt években kezdett elterjedni a modern okoseszközöknek köszönhetöen. ${ }^{1}$ Az AR mint technológia napjainkban leginkább 


\section{NETWORKSHOP 2018}

mobil, valamint dedikált eszközökkel megjelenített virtuális tartalom a valós térben. ${ }^{2}$ Mobilok esetében egy modern okostelefon, amit a többségünk is nap mint nap használ, dedikált eszköz esetében pedig valamilyen céleszköz, pl. egy Microsoft HoloLens lehet megoldás. A könyvtári szakmában azonban ezek a lehetőségek még nem igazán terjedtek el. A közgyűjtemények esetében elsősorban a kiállítási terek nyitottak az élményalapú tartalomszolgáltatásra, föként külföldön. ${ }^{3}$ Ilyenek például a National Museum of Singapore vagy a Smithsonian National Museum of Natural History tematikus gyűjteményei.

A kiterjesztett valóság alkalmazása egy általános, egyszerü példán keresztül bemutatva: adott egy QR kód (Quick Response Code), amit ha a készülékünkkel beolvasunk, valamilyen extra tartalmat jelenítünk meg. Ez lehet akár böngészőben egy weboldal, esetleg egy névjegy, melyet elmenthetünk. Ugyanezen az elven müködik egy vonalkód, amit beolvasva extra információt kaphatunk egy könyvröl, termékröl. Esetünkben azonban fontos megemlíteni, hogy ezekkel ellentétben ilyenkor interakcióba is léphetünk az adatokkal a telefonunk kijelzőjén megjelenő virtuális, esetleg a térben elhelyezett gombokon keresztül. A dedikált eszközökkel szemben azért érdemes mobiltelefonokról beszélnünk, vagy ezeket választani célplatformnak, mert azok jelenleg sokkal elterjedtebbek. Ezen eszközök is alkalmasak a megjelenítésre, mely több módon történhet: a legfontosabb, hogy valami alapján a készülékünk azonosítani tudja azt, hogy mit és hol kell megjelenítenie, feldolgoznia. A legjobb, hogy a legelterjedtebb rendszerekre, mint az iOS vagy Android, a fejlesztőprogramok megadják a lehetőséget a tartalom vizualizációjára. Ahhoz azonban, hogy ez megjelenjen, el kell döntenünk, hogy mi alapján szeretnénk, hogy a készülékünk azonosítani tudja, mit is akarunk megjeleníteni: ez történhet akár hely alapú - koordinátákkal - történő azonosítással, vagy valamilyen markerrel - jelző segítségével.

\section{Azonosítási lehetőségek}

\subsection{Hely alapú, koordinátás azonosítás}

Koordináták esetében legtöbb esetben GPS-modult alkalmazhatunk mint a legelterjedtebb megoldás. Ezzel azonban probléma adódhat egy épületen belül oly módon, hogy a magasságot egyáltalán, a távolságot pedig nem pontosan kezeli. Külső tényezőként akár az időjárás is befolyásolhat. A GPStechnológia esetében a folyamatos adatkommunikáció miatti akkumulátorterhelés szintén negatívan befolyásolja a technológia népszerüségét. Elérhető azonban egy ígéretes alternatíva, mely a WiFikapcsolat alapján határozza meg a helyet, erre szolgál a WiFi RTT (round-trip time) technológia. Ennek segítségével pontos helyazonosítást érhetünk el zárt helyeken is kompatibilis eszközök használatával. A technológia várhatóan széles körben el fog terjedni annak köszönhetően, hogy az Android Pie verziótól már rendszerszinten támogatni fogja ennek kezelését. Így a jövőben ezekkel a lehetőségekkel is élhetünk majd.

\footnotetext{
$2 \quad$ Hosch, William L. „Augmented Reality.” Encyclopcedia Britannica, inc. , Hozzáférés: 2016. 05. 13. https://www.britannica.com/technology/augmented-reality

3 Jung, Timothy, M. Claudia tom Dieck, Hyunae Lee, és Namho Chung. „Effects of Virtual Reality and Augmented Reality on Visitor Experiences in Museum" Information And Communication Technologies In Tourism 621. Bilbao, Spanyolország: Springer, (2016). 621-636. Hozzáférés: 2018. 06. 18.

https://doi.org/10.1007/978-3-319-28231-2_45
} 
Ezzel igazán látványos megjelenítést lehet elérni - például, ha egy katalógussal összekötjük, akkor adott könyveket azok lelöhely adatai alapján megjeleníthetünk és oda is vezethetjük a felhasználókat, hiszen az alkalmazás megmutatja nekik azok lelőhelyét. Ez esetben fontos, hogy legyen olyan adatbázisunk, mely tárolja a könyvek helyét - akár lelőhely-információk alapján -, melyet aztán az alkalmazásban lekérhetünk és megjeleníthetünk. Ezeken felül fontos, hogy eszközünk pozíciója is ismert legyen, mert csak ezek alapján tudjuk a virtuális térben megjeleníteni az adatokat.

\subsection{Markeres azonosítás}

Az offline szolgáltatásokat tekintve azonban érdemesebb lehet markereket alkalmazni, melyeket kihelyezve a felhasználók készülékük kamerájával beolvasva juthatnak hozzá a virtuális tartalomhoz, plusz információhoz. Ez egyrészről praktikus lehet, hiszen így sokkal energiahatékonyabb lehet az alkalmazás, másrészről ténylegesen csak tudatos interakció után jelenik meg a kívánt tartalom. Ezáltal a marker célja a felhasználó és a tartalom összekötése. Jellegét tekintve fontos, hogy számos ponton tudja azt telefonunk azonosítani, mely az alkalmazáson belül történik, így a megjelenített modell ténylegesen a „helyén” marad. A bevezetőben említett, általunk fejlesztett alkalmazás is ezt a technológiát veszi alapul. Ennek kialakításakor fontos szempont volt, hogy az azonosítandó ábra elég kontrasztos kép

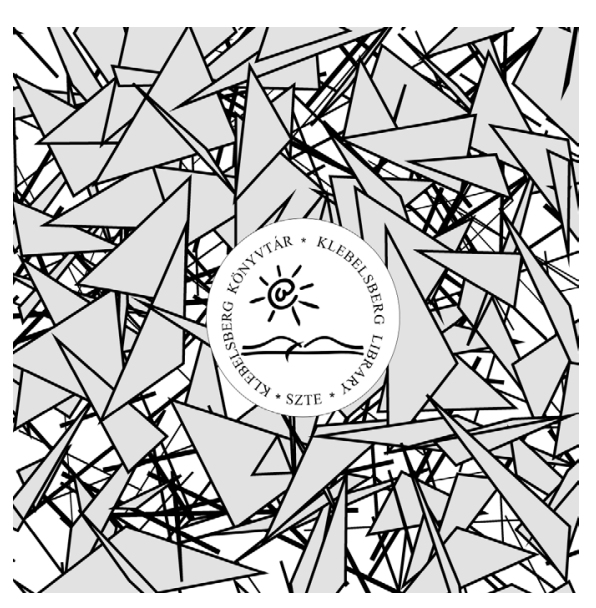

1. ábra Az SZTE KK - AR Experience alkalmazás markere legyen, valamint lehetőség legyen vektoros formában is szerkeszteni. Az 1. ábrán az SZTE Klebelsberg Könyvtár logójával ellátott egyedi marker látható, mely megfelel a fenti követelményeknek. Amennyiben több ilyet szeretnék alkalmazni, úgy arra a lehetőség adott, akár legyenek ezek egyformák, akár különbözőek. Ilyen szempontból ez csak fejlesztés kérdése, és a technológia lehetővé tenné több szín megjelenítését is, így nem feltétlenül kell fekete-fehér képben gondolkodnunk, így lehet egy marker egyedi, a könyvtár igényeire szabott.

\section{SZTE KK - AR Experience}

\subsection{Gyakorlat}

Az SZTE Klebelsberg Könyvtár alkalmazása az SZTE KK - AR Experience nevet viseli és a prezentáció jegyében a könyvtárban megtalálható „Szieszta Polc” került modellezésre. A polc maga egy kisebb gyűjtemény, mely a friss, népszerü és szórakoztató irodalom köteteit foglalja magában. Az alkalmazás célja, hogy információt juttasson el annak használójához interaktív módon. Ennek köszönhetően a felhasználó önállóan képes megismerni a polcon található gyűjteményt, azon tudja, mit hol talál, segíti eligazodni. Az elképzelés arra alapult, hogy egy felhasználó, aki használja a készülékét és telepíti az alkalmazást, önállóan ismerhesse meg a könyvtárat, ezzel egyfajta felfedezési élményt is garantálhatunk. A modellhez valamint az extra tartalomhoz való eljutás így igen egyszerü: a könyvtári appot telepítjük jelenleg bármilyen minimum 5.1-es Androidot futtató készülékre -, a fentebb látott markert beolvassuk, ezután az alkalmazásban definiált módon a telefon azonosítja azt, majd annak ismert pozíciójához mérten 


\section{NETWORKSHOP 2018}

a tartalmat - jelen esetben a polcot - megjeleníti. (lásd 2. ábra) Ezt követően az alkalmazás gombjaival a modell szabadon változtatható, azzal interakció kezdeményezhető.

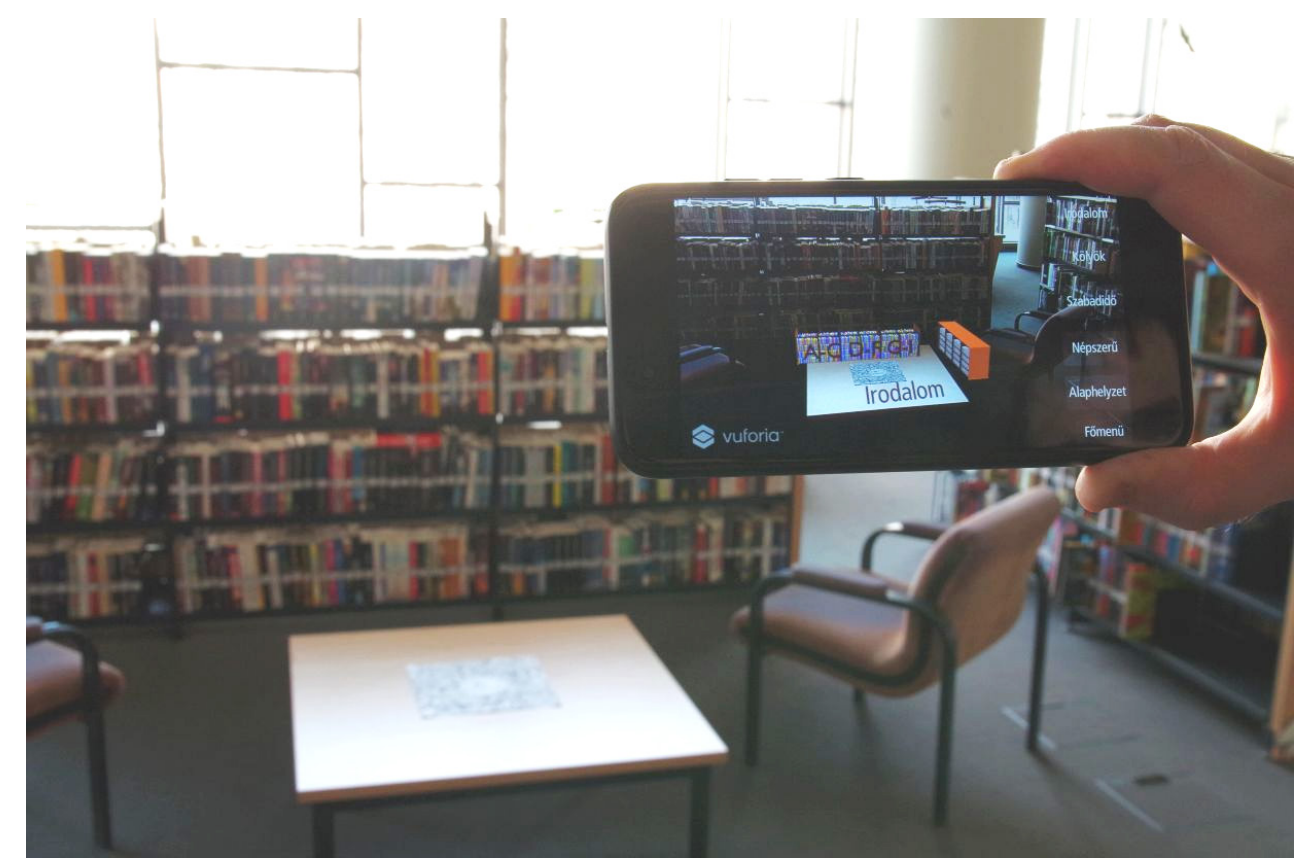

2. ábra Az Irodalom témát kiválasztva megjelenő modell

\subsection{Fejlesztés}

A fejlesztéshez mindösszesen hat eszközre volt szükségünk. Négy programra, egy számítógépre valamint egy okostelefonra. A programok, amiket használtunk, teljes mértékben ingyenesen elérhetőek: a 3D modell Blenderben készült, a markereket a Vuforia környezete tette azonosíthatóvá, a felhasználói felület, interakció megvalósulása és az egész program további tervezése pedig az Unity grafikus motorban történt. Ezeken felül szükséges még az Android-rendszerü fejlesztéshez az Android Studio megléte. Ez azért is fontos, hiszen ugyan elérhetőek olyan szoftverek, melyek szolgáltatásait használhatjuk kiterjesztett valóságra (lásd pl. Aurasma, Layar), azonban így az elkészült alkalmazás teljesen független ezektől.

Mint szoftver azonban ez is rendelkezik minimális rendszerkövetelményekkel. Ezek nem specifikusak, minden minimum 5.1-es Androidot futtató készüléken elfut, azonban a hardveres képességektöl függően a modell megjelenítése sokkal jobb lehet egy „erősebb” készülék esetében.

\section{Alkalmazás}

\subsection{Felhasználók}

Maga az AR a közmüvelödésben és a könyvtárakban még kiaknázatlan terület. Amennyiben az ilyen jellegü digitális anyagok is jobban elterjednek, úgy azokat a könyvtáron keresztül is lehetne szolgáltatni. Ha a könyvtáraknak vannak ilyen jellegü elöfizetett tartalmai, akkor a klasszikus értelemben vett tartalomszolgáltatás is megvalósulhat az AR tekintetében. A legkézenfekvőbb példa azonban a felhasználók könyvtári tájékoztatása illetve önálló tájékozódási képességének javítása lenne, akár 
markerek segítségével, akár koordinátákkal. Itt felhasználhatóak lennének a térképek, iránymutatók vagy más digitális anyagok is, valamint egy-egy érdekes vagy központi helyen elhelyezett marker. Ezekkel extra tartalmakat lehet bemutatni, ezek alatt pedig a könyvtári szolgáltatások hirdetését valamint ajánlásokat lehet hozni.

Ez a típusú szolgáltatás pedig nemcsak statikusan egy-egy adott könyvhöz kapcsolódva jelenhet meg, hanem állományokhoz is. Ezáltal egy teljesen másmilyen élményt kap a felhasználó a könyvtártól - vagy más közintézménytől - mindazon túl, hogy hasznára válik annak megismerése az interaktivitásnak hála. A jövőben ez nemcsak egyszeri látványosság lehet, hanem egy teljes értékü, önálló szolgáltatási platformként alkalmazható.

\subsection{Intézmények}

Intézmények esetében is hasznos lehet a már említett külső fejlesztésű alkalmazások esetében, melyek az oktatás valamilyen részéhez kapcsolódva dolgoznak fel anyagot. ${ }^{4}$ Ezeket a könyvtári tartalomszolgáltatásba beépítve tudnánk a felhasználók rendelkezésére bocsátani. Itt kihasználható, hogy már elérhetőek olyan könyvek, anyagok akár kutatásokhoz, oktatáshoz is, melyeket AR formában is illusztrálnak. Ezeken túl a könyvtárosoknak is segítséget nyújthat: a legkézenfekvőbb példa a felhasználók könyvtári tájékoztatása, illetve a könyvtáron belüli állománykezelés - inkább a leltározás szempontjából. Ilyenkor a könyvgerincre ragasztott markeres azonosítással, ha az összeköttetésben áll a könyvtár állományával, megállapítható, hogy mely könyvek vannak meg és érhetőek el. ${ }^{5}$ Ez hosszabb távon az RFID egy lehetséges alternatívája lehet, azonban megvalósítása nehézkes, ugyanis ennek egy részét szabadalom védi. ${ }^{6}$

\section{5. Összegzés}

Az AR hasznos platformja lehet a tartalomszolgáltatásnak. Helyi szinten érdemesebb markert alkalmazni, mely használható állományrészekhez, gyüjteményekhez kötve is akár. Érdekes pontokon elhelyezve extra tartalom bemutatására, marketingre, játékokra. Az SZTE Klebelsberg Könyvtárban megvalósult alkalmazás célja, hogy ingyenes hozzáféréssel, tudatos fejlesztéssel hasznos információt mutasson be. Célja az önálló tájékozódás és plusz információ nyújtása.

A mobiltelefonok és a virtuális tartalmak a mindennapjaink részei, előbb-utóbb pedig eljöhet az a helyzet, hogy az ilyen típusú tartalmakra megjelenik a - jogos - igény. Ezáltal otthonosabb környezetet teremthetünk a fiatal felhasználóknak, akik egyre szélesebb körben alkalmazzák a modern technológiát, és ehhez hosszabb távon a könyvtáraknak is igazodnia kell. Ha a jövőben a közgyűjtemények szeretnének új területeken is szolgáltatni és ezáltal egy teljesen új oldalukat megmutatni, úgy érdemes a digitális tartalom felé is nyitni és a technológiai újításokat alkalmazni. A kiterjesztett valóság egy igen széleskörüen alkalmazható eszköz lehet a jövőben, a digitális tartalom pedig extra teret kaphat mind a mindennapi, mind az online és offline tartalomszolgáltatás tekintetében is.

$4 \quad$ Peng, Chen, Xiaolin Liu, Wei Cheng, és Ronghuai Huang. „A review of using Augmented Reality in Education from 2011 to 2016." Innovations in Smart Learning (Springer International Publishing), (2017) 13-18. Hozzáférés: 2018. 06. 18. https://doi.org/10.1007/978-981-10-2419-1_2

5 Brinkman, Bo, és Brinkman. Stacy. „AR in the library: A pilot study of multi-target acquisition usability.” 2013 IEEE International Symposium on Mixed and Augmented Reality (ISMAR). IEEE, 2013. Hozzáférés: 2018. 06. 18. https://doi.org/10.1109/ISMAR.2013.6671785 